\title{
VITAMIN A AND LIPID PEROXIDATION IN PATIENTS WITH DIFFERENT FORMS OF LEPROSY
}

\author{
Emerson S. LIMA(1), Ivete de A. ROLAND(2), Maria de Fátima MAROJA(3) \& Jaydione L. MARCON(4)
}

\begin{abstract}
SUMMARY
Leprosy, a chronic infectious disease, is caused by a Mycobacterium leprae infection. After India, Brazil has the second greatest number of cases in the world. Increase of oxidative stress and antioxidant deficiency are present in infected subjects and can be related to infection progression. We studied alterations in serum levels of lipid peroxidation (LPO) and vitamin A in patients with different forms of leprosy. Four groups of leprosy patients and a control group (healthy subjects) were selected, and their vitamin A serum levels and LPO profile, measured as malonaldehyde (MDA) were measured by spectrophotometric assays. The mean MDA serum levels $(\mu \mathrm{mol} / \mathrm{L})$ were $3.80 \pm 0.5$ for control group and $10.54 \pm 1.1$ in the leprosy patients and this increase was gradual, being more accentuated in severe forms of the disease. Also, the vitamin A serum levels ( $\mu \mathrm{g} / \mathrm{dL}) \mathrm{were}$ diminished in the infected subjects $(38.51 \pm 4.2)$, mainly in lepromatous form, when compared with the control group (53.8 \pm 5.6$)$. These results indicate that LPO can be an important factor in Mycobacterium leprae infection, which can be related to increases in phagocytic activity and the general breakdown of antioxidants, contributing to an increase of LPO during infection progression. The evaluation of oxidant/antioxidant status in these patients can be an important factor in the treatment, control, and/or prognosis of this disease.
\end{abstract}

KEYWORDS: Leprosy; Vitamin A; Lipid peroxidation; Malondialdehyde.

\section{INTRODUCTION}

Leprosy or Hansen disease is caused by an infection by Mycobacterium leprae. Brazil has the second greatest number of cases in the world after India. The World Health Organization initially set a target goal for eliminating the disease world-wide by the year 2000, yet this date was postponed to 2005 and has still not been obtained by Brazil.

M. leprae is an obligatory intracellular parasite with affinity for the cells of Schwann and the reticuloendothelial system, mainly macrophages ${ }^{15}$. In leprosy patients, the development of the infection depends upon the quality of the immunological response. If the response is effective, the infection will produce a non-contagious localized expression of the disease; however, if the response is not effective, an intermediate form develops, reflecting a wide spectrum of resistance ${ }^{4}$. The defense mechanism has primordial participation of the macrophages, lymphocytes, and its cytokines, regulating the production, release and modulation of diverse and important cellular immunity reactions. In the tuberculoid form, this response is predominantly cellular, while lepromatous typically shows a humoral defense $\mathrm{e}^{4}$.

Several substances with recognized antioxidant potential, such as retinol (vitamin A), $\alpha$-tocopherol (vitamin E), acid ascorbic (vitamin
C), zinc, magnesium and selenium have been shown to decrease in different forms of leprosy ${ }^{11,12,14,16}$. A decrease of antioxidant status can contribute to an increase of oxidative stress and complicate the treatment and the control of these patients. The measurement of malondialdehyde (MDA) serum levels in association with the determination of the antioxidant status can constitute an important tool in prognosis, treatment, and control of leprosy patients or other degenerative disease $^{12}$.

In the present study, the serum levels of lipid peroxidation (measured as MDA) and vitamin A were determined in patients with the different forms of leprosy. These parameters were compared in subjects with different forms of the disease and no leprosy.

\section{MATERIAL AND METHODS}

Patients: Forty-three patients attending the Foundation of Dermatology and Venereology "Alfredo da Matta" (FUAM) were selected and divided into four groups according to forms of leprosy: Indeterminate $(n=11)$, tuberculoid $(n=12)$, borderline $(n=10)$ and lepromatous $(\mathrm{n}=10)$. The patients had clinical diagnosis, as previous criteria $^{6}$, and had not been previously submitted to drug treatment. Also, healthy subjects $(\mathrm{n}=11)$ were selected as control group. Participants age varied between 20 and 60 years. Volunteers who were 
identified through a questionnaire as positive for other diseases were excluded from the study. All the participants signed written informed consent forms, authorizing the use of their samples in this study, which was approved by the Ethics Committee for Human Research of the FUAM.

Samples: Blood samples $(5 \mathrm{~mL})$ were collected from the cubital vein in the morning. Subjects fasted for $12 \mathrm{~h}$ before sample collection. The venous blood samples were centrifuged at $2500 \mathrm{rpm}$ for $15 \mathrm{~min}$. The serum samples were then stored at $-20{ }^{\circ} \mathrm{C}$ until biochemical analysis.

\section{Analytical procedures}

MDA test: MDA serum levels were determined by thiobarbituric acid reactive substances (TBARs) assay, according to OHKAWA et $a l .{ }^{10}$, and $200 \mu \mathrm{L}$ of serum was added and briefly mixed with $1 \mathrm{~mL}$ of trichloroacetic acid at 30\%, $0.9 \mathrm{~mL}$ of TRIS-HCl (pH 7.4), and $1 \mathrm{~mL}$ of thiobarbituric acid $0.73 \%$. After vortex mixing, samples were maintained at $100{ }^{\circ} \mathrm{C}$ for 60 minutes. Afterwards, samples were centrifuged at $3000 \mathrm{rpm}$ for $10 \mathrm{~min}$ and supernatant read at $535 \mathrm{\eta m}$. The signal was read against an MDA standard curve, and the results were expressed as $\mu \mathrm{mol} / \mathrm{L}$.

Vitamin A measurement: The vitamin A serum levels were determined by a spectrophotometric method with ultraviolet light inactivation $^{2}$. Briefly, after mixing $500 \mu \mathrm{L}$ of serum with $500 \mu \mathrm{L}$ of alcoholic $\mathrm{KOH}$, vitamin A was extracted by a coefficient of partition in a kerosene-xylene mixture $(2 \mathrm{~mL})$. After centrifugation for 15 minutes at 3,000 rpm, the supernatant was read at $328 \mathrm{\eta m}$. The absorbance was proportional to vitamin A concentration in the sample. The signal was read against a retinol standard curve and the results were expressed as $\mu \mathrm{g} / \mathrm{dL}$.

Statistical analyses: All parameters were given as mean \pm sd. Data were analyzed statistically by ANOVA and by multiple comparisons between groups (Tukey's test). Correlations between MDA and vitamin A were also examined by Pearson Correlation test. The tests were performed using the SigmaStat 2.03 software (Jandel Scientific, Chicago). Statistical significance for all tests was accepted at $p<0.05$.

\section{RESULTS}

The MDA serum levels (mean $\pm \mathrm{sd}$ in $\mu \mathrm{mol} / \mathrm{L}$ ) were $3.8 \pm 0.5$ in control group, $9.8 \pm 1.5$ in undetermined, $10.1 \pm 1.1$ in tuberculoid, $10.1 \pm 0.9$ in borderline and $12.2 \pm 1.0$ in patients with lepromatous form. MDA serum levels were increased with statistical significance when this last group was compared with the control group. Thus, this increase was gradual and corresponded to the different periods of development of the disease, being more accentuated in the patients of the lepromatous form (Fig. 1). The vitamin A serum levels (mean $\pm \mathrm{sd}$ in $\mu \mathrm{g} / \mathrm{dL}$ ) were $53.8 \pm 5.6$ in control group, $42.3 \pm 7.0$ in undetermined, $40.3 \pm 6.2$ in tuberculoid, $38.9 \pm 6.2$ in borderline and $32.5 \pm 8.4$ in lepromatous form. In the leprosy patients, the vitamin A levels were diminished in relation to the control group; however, only the lepromatous form presented statistically significant lower levels of vitamin A (Fig. 2). In addition, when vitamin A and MDA levels of the patients with different forms of leprosy were compared through the analysis of Pearson Correlation, an inverse correlation was shown ( $p=0.012$, Fig. 3).

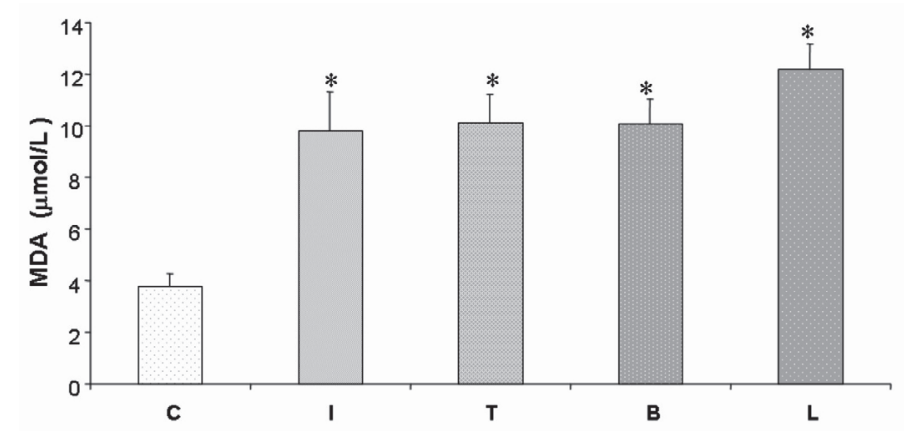

Fig. 1 - MDA serum levels (mean $\pm \mathrm{sd}$ in $\mu \mathrm{mol} / \mathrm{L}$ ) in control subjects and leprosy patients. C $=$ control group $(3.8 \pm 0.5), \mathrm{I}=$ indeterminate $(9.8 \pm 1.5), \mathrm{T}=$ tuberculoid $(10.1 \pm 1.1), \mathrm{B}=$ borderline $(10.1 \pm 0.9), \mathrm{L}=$ lepromatous $(12.2 \pm 1.0)$. (*) Statistically significant differences vs. control group $(p<0.05)$

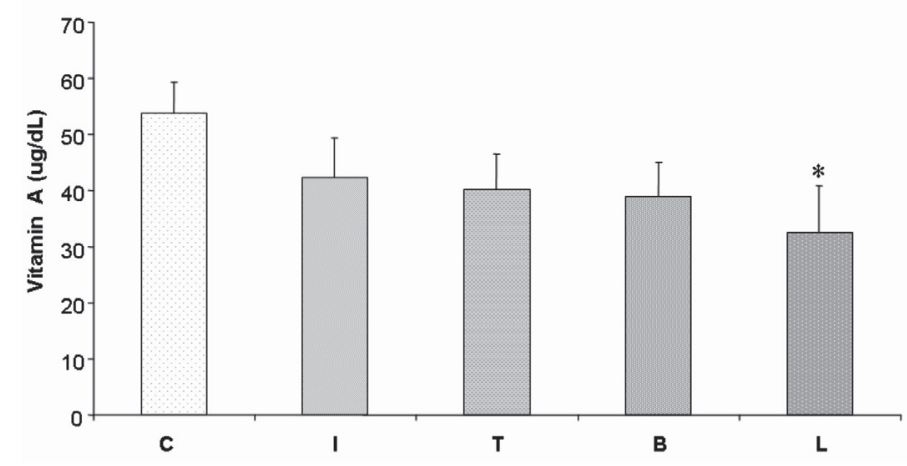

Fig. 2 - Vitamin A serum levels (mean $\pm \mathrm{sd}$ in $\mu \mathrm{g} / \mathrm{dL}$ ) in control subjects and leprosy patients. $\mathrm{C}=$ control group $(53.8 \pm 5.6), \mathrm{I}=$ indeterminate $(42.3 \pm 7.0), \mathrm{T}=$ tuberculoid $(40.3 \pm 6.2)$, $\mathrm{B}=$ borderline $(38.9 \pm 6.2), \mathrm{L}=$ lepromatous $(32.5 \pm 8.4)$. (*) Statistically significant differences vs. control group $(p<0.05)$.

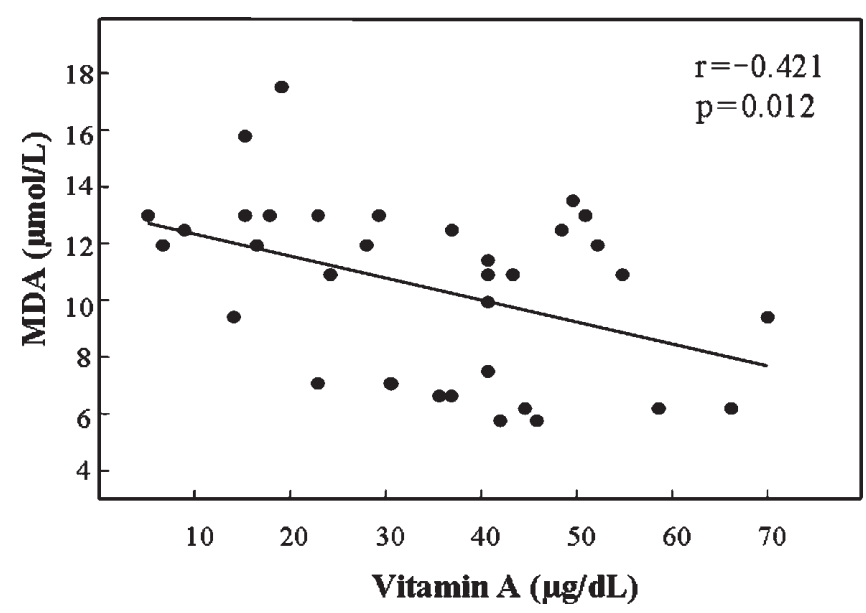

Fig. 3 - Correlation between vitamin A $(\mu \mathrm{g} / \mathrm{dL})$ and MDA $(\mu \mathrm{mol} / \mathrm{L})$ serum levels in leprosy patients. (Pearson correlation test, $\mathrm{r}=-0.421 ; p=0.012 ; \mathrm{n}=35$ ). 


\section{DISCUSSION}

The antioxidant deficiency reported in the literature for different forms of leprosy, mainly in the lepromatous form ${ }^{11}$, could be related to the increase of the levels of MDA observed in the present work. It was observed that the vitamin A levels in the serum of the leprosy patients, mainly in the lepromatous form, diminished in relation to the control, which is consistent with the literature ${ }^{11,12}$. As vitamin A is directly related to maintenance of the cellular membrane structure, it is possible that the reduction of vitamin A contributes to an increase in the production of MDA in these individuals. Increased levels of MDA have also been found in renal tissue of mice infected with $M$. leprae ${ }^{1}$. Also, some authors have described an increase in phagocytic activity in leprosy ${ }^{3,15}$.

The induction of the macrophages in response to the infection of the $M$. leprae could contribute to an increase in MDA levels since phagocytosis is a potential mechanism in reactive oxygen species (ROS) production $^{3}$. This aspect can be physiologically important; however, to intensify the production of the ROS, the macrophages are rendered inefficient in eliminating bacilli in the borderline or lepromatous forms ${ }^{4}$. This cascade of events could also be responsible for the increase of MDA levels in the leprosy patients, mainly in the cases of the lepromatous form, since the immunological response of the organism is predominantly lymphocyte $\mathrm{B}$ dependent ${ }^{15}$. The inefficient action of the macrophages on the $M$. leprae could increase the oxidative effects on other cells of the host organism, as the erythrocytes and adjacent tissues, contributing still more to the establishment of oxidative stress in the patients with borderline (with variations) and lepromatous forms. The increasing of MDA levels in different forms of the leprosy, mainly in lepromatous form, could be interpreted as intensifying the oxidative stress to which these patients are submitted.

On the other hand, leprosy is a disease of chronic evolution, releasing cytokines in the circulation throughout the life span of infected individuals. These substances inhibit the action of the 3-Hydroxy-3methylglutaryl coenzyme A reductase, an essential enzyme in the synthesis of cholesterol from acid mevalonic. It is probable that, with the reduction of the cholesterol synthesis, this enzyme reduced the synthesis of very low density lipoprotein and low density lipoprotein production, which are transporter of lipo-soluble vitamins, including vitamin $\mathrm{A}^{7}$. This cascade of events could result in the reduction of vitamin A levels in the serum, and this would explain, in part, the reduction of vitamin A levels observed in the serum of the leprosy patients. Vitamin A deficiency has been identified in leprosy patients of other countries, such as India ${ }^{11}$, mainly in patients with more accentuated forms ${ }^{5}$ and also in patients of the Amazon ${ }^{13}$. These results were also confirmed in the present work, indicating the existence of a possible functional relation between the levels of this vitamin and the levels of MDA in the leprosy patients.

In conclusion, our results suggest that MDA serum levels increase in leprosy patients in comparison with subjects with no leprosy, and vitamin A serum levels were intensely reduced in lepromatous form of this disease. Moreover, the reduction of this antioxidant, combined with the impoverished social conditions as well as undernutrition found in the majority of leprosy patients, may contribute to reducing the success rate in the treatment and recovery of these patients. Moreover, it is important to point out that none of the patients of this study used specific treatment with drugs such as dapsone and clofazimine, which can exacerbate oxidative stress ${ }^{8,9}$. The introduction of a diet or antioxidant therapy supplemented by vitamins and minerals could be beneficial for these patients, attenuating the toxic actions caused by the ROS and propitiating an adjusted treatment and recovery, thus possibly improving the quality of life of these subjects.

\section{RESUMO}

\section{Vitamina A e peroxidação lipídica em pacientes com diferentes formas de hanseníase}

A hanseníase, doença infecciosa crônica, é causada pelo Mycobacterium leprae. Depois da Índia, o Brasil possui o segundo maior número de casos no mundo. $\mathrm{O}$ aumento do estresse oxidativo e da deficiência das defesas antioxidantes estão presentes em indivíduos infectados e podem associar-se à progressão da infecção. Foram estudadas alterações nos níveis séricos da peroxidação lipídica e vitamina A em pacientes com diferentes formas de hanseníase. Foram selecionados para o estudo quatro grupos de pacientes com hanseníase e um grupo controle (indivíduos saudáveis) e os níveis séricos de vitamina A e a peroxidação lipídica, medida através do malondialdeído (MDA), foram determinados por métodos espectrofotométricos. Os níveis séricos médios de MDA ( $\mu \mathrm{mol} / \mathrm{L}$ ) foram 3,80 \pm 0,5 no grupo controle e 10,54 $\pm 1,1$ nos pacientes com hanseníase. Sendo este aumento gradual e exacerbado nas formas mais severas da doença. Quanto à vitamina $\mathrm{A}$, os níveis séricos $(\mu \mathrm{g} / \mathrm{dL})$ encontraram-se diminuídos nos indivíduos infectados $(38.51 \pm 4.2)$, principalmente na forma lepromatosa, quando comparados com o grupo controle $(53.8 \pm$ 5.6). Estes resultados indicam que a peroxidação lipídica pode ser um fator importante na infecção mediada pelo Mycobacterium leprae podendo estar relacionada ao aumento da atividade fagocítica pelos macrófagos contribuindo para um aumento da LPO durante a progressão da infecção. A avaliação do perfil oxidante/antioxidante nestes pacientes pode ser um fator importante no tratamento, controle e/ou prognóstico desta doença.

\section{ACKNOWLEDGMENTS}

We would like thanks to Dra. Marina Helyde and Dra. Lúcia Kiyoko Ozaki Yuyama for the contribution in the dosage of the vitamin A and the team of the Laboratory of Experimental Nutrition in the National Institute of Research of the Amazônia (INPA).

\section{REFERENCES}

1. AGNIHOTRI, N.; GANGULY, N.K.; KAUR, S. et al. - Role of reactive oxygen species is renal damage in experimental leprosy. Lepr. Rev., 66: 201-209, 1995.

2. ARAÚJO, C.R.C. \& FLORES, H. - Improved spectrophotometric vitamin A assay. Clin. Chem., 24: 386-390, 1978.

3. BABIOR, B.M. - Oxidants from phagocytes: agents of defense and destruction. Blood, 64: $959-966,1984$

4. BRITTON, W.J. - Immunology of leprosy. Trans. roy. Soc. trop. Med. Hyg., 87: 508514, 1993.

5. CHATTOPADHYA, D.; SAHA, K.; CHAKRABARTY, A.K. et al. - Nutritional status of children of urban leprosy patients staying at preventoria based on biochemical parameters. Europ. J. clin. Nutr., 46: 885-895, 1992. 
6. GATICA, L.V; VEGA, V.A., ZIRULNIK, F; OLIVEROS, L.B. \& GIMENEZ, M.S. Alterations in the lipid metabolism of rat aorta: effects of vitamin A deficiency. $\mathbf{J}$. Vasc. Res., 43: 602-610, 2006.

7. JOPLING, W.H. - Handbook of leprosy. 2. ed. London, Heinemann, 1978.

8. LARDO, M.M.; DIAZ, N.B.; ARTAZA, J.R. et al . - Vitamin E as protective agent against hemolysis in leprosy patients under dapsone treatment. Medicina (B. Aires), 57:150154, 1997.

9. McMiLlAN, D.C.; JENSEN, C.B. \& JOLLOW, D.J. - Role of lipid peroxidation in dapsone-induced hemolytic anemia. J. Pharmacol. exp. Ther., 287: 868-876, 1998.

10. OHKAWA, H.; OHISHI, N. \& YAGI, K. - Assay for lipid peroxides in animal tissues by thiobarbituric acid reaction. Analyt. Biochem., 95: 351-358, 1979.

11. RAO, K.N. \& SAHA, K. - Undernutrition and lepromatous leprosy. Serum vitamin A and E levels in leprosy spectrum. Indian J. Lepr., 60: 66-70, 1988.

12. REDDY, Y.N.; MURTHY, S.V.; KRISHNA, D.R. et al. - Oxidative stress and anti-oxidant status in leprosy patients. Indian J. Lepr., 75: 307-316, 2003.
13. SALEM, J.I.; FERRARI, I.; SOUZA, A.T.O. et al. - Transformação blástica em pacientes hansenianos: correlação com vitamina A e zinco. Rev. Univ. Amaz. Ser. Cien. Saúde, 1: 63-70, 1992.

14. SAXENA, N.; SHARMA, R.P. \& SINGH, V.S. - Study of serum zinc level in leprosy. Indian J. Lepr., 60: 556-561, 1988.

15. SPIERINGS, E.; DE BOER, T.; ZULIANELLO, L. \& OTTENHOFF, T.H. - The role of Schwann cells, T cells and Mycobacterium leprae in the immunopathogenesis of nerve damage in leprosy. Lepr. Rev., 71(suppl.): S121-S129, 2000.

16. VIJAYARAGHAVAN, R.; SURIBABU, C.S.; SEKAR, B. et al. - Protective role of vitamin E on the oxidative stress in Hansen's disease (Leprosy) patients. Europ. J. clin. Nutr., 59: 1121-1128, 2005.

Received: 12 September 2006

Accepted: 22 December 2006 